\title{
Impact of Charging Rates on Electric Vehicle Battery Life
}

\author{
Sivapriya Mothilal Bhagavathy ${ }^{1}$ (D, Hannah Budnitz ${ }^{2}$ (D, Tim Schwanen ${ }^{2}$ (D, Malcolm McCulloch ${ }^{3}$ (D) \\ ${ }^{1}$ Engineering Science, University of Oxford, ${ }^{2}$ Transport Studies Unit, University of Oxford, ${ }^{3}$ Energy and Power Group, University of Oxford \\ Keywords: charging rate, rapid charging, battery degradation, battery electric vehicle \\ $10.32866 / 001 c .21459$
}

Findings

This article synthesizes the sparse empirical literature on the impact of different charging rates on electric vehicle battery life with a focus on popular electric car models. The findings show that rapid and ultra-rapid charging cause more degradation of the most common electric vehicle batteries than fast charging, although this degradation is limited to an extent by battery management systems. The information in this article can aid in planning the expansion of different types of charging infrastructure and be used to inform drivers who are switching to battery electric vehicles.

\section{Questions}

The transition to electric vehicles (EVs) is seen as an important means to reduce global carbon emissions from the transport sector, but a number of barriers to mass adoption of EVs have been identified. Technical concerns such as battery range, charging time, and battery life are prominent among these, particularly for battery-only EVs as compared to hybrids (Biresselioglu, Kaplan, and Yilmaz 2018). Increased battery sizes increase the range of EVs and the provision of rapid charging infrastructure reduces charging time, but we ask what effect these have on the third concern of EV battery life?

We aim to answer this question, whilst considering the impact of charging speeds on battery life more generally. We also have identified a lack of clear guidance for prospective EV purchasers and for charging infrastructure providers on the interactions between battery types, range, charging times, rate of charge, and battery life. Therefore, we aim to fill this gap with a simple table providing this information for ten of the most common private electric cars on the market today.

\section{Methods}

We define battery life and the processes causing battery degradation, then review the sparse literature empirically testing battery degradation. As degradation and the impact of charging speeds are dependent on the size and type of battery, we use web searches to synthesize information on how choosing different charging options affect battery life for common EV models in the UK.

All batteries degrade with time and use. Most EVs have a warranty for eight years or 100,000 miles, whichever is earlier. An EV battery is considered at end of its life if it no longer maintains $80 \%$ of total usable capacity and has more than 5\% self-discharge rate over a 24-hour period (Engel et al. 2019). 
Table 1: Literature on the influence of charging rate on battery degradation

\begin{tabular}{|l|l|l|l|l|}
\hline Reference & $\begin{array}{l}\text { Type of } \\
\text { battery }\end{array}$ & $\begin{array}{l}\text { Number } \\
\text { of } \\
\text { batteries } \\
\text { tested }\end{array}$ & $\begin{array}{l}\text { Charging } \\
\text { rate of } \\
\text { tests }\end{array}$ & Conclusion \\
\hline $\begin{array}{l}\text { Gao et al. } \\
\text { (2017) }\end{array}$ & $\begin{array}{l}18650 \text {-type } \\
\text { NMC }\end{array}$ & 21 & $\begin{array}{l}0.5 \mathrm{C}, \\
0.8 \mathrm{C}, 1 \mathrm{C}, \\
1.2 \mathrm{C}, \\
1.5 \mathrm{C}\end{array}$ & $\begin{array}{l}\text { NMC battery degrades significantly on C-rates higher than } 1 . \\
\text { Battery degrades by } 10 \% \text { and } 23 \% \text { at } 1.2 \mathrm{C} \text { and } 1.5 \mathrm{C} \text { respectively } \\
\text { at the end of } 300 \text { cycles as against degradation by } 7 \% \text { at } 1 \mathrm{C} .\end{array}$ \\
\hline $\begin{array}{l}\text { Somerville } \\
\text { et al. } \\
(2016)\end{array}$ & $\begin{array}{l}18650 \text {-type } \\
\text { NMC }\end{array}$ & 12 & $\begin{array}{l}0.7 \mathrm{C}, 2 \mathrm{C}, \\
4 \mathrm{C}, 6 \mathrm{C}\end{array}$ & $\begin{array}{l}\text { Increased charging rates negatively affect the lifetime. Charging } \\
\text { at rates higher than } 4 \mathrm{C} \text { alters the chemical composition resulting } \\
\text { in significant damage and reduction of life. }\end{array}$ \\
\hline $\begin{array}{l}\text { Anseán et } \\
\text { al. (2016) }\end{array}$ & LFP & 3 & $\begin{array}{l}1 \mathrm{C}, 4 \mathrm{C} \\
\text { Capacity degradation is } 15 \% \text { at } 1 \mathrm{C} \text { and } 17 \% \text { at } 4 \mathrm{C} \text { after } 4,000 \\
\text { cycles. Up to } 1000 \text { cycles, the degradation from both charging } \\
\text { rates are similar. }\end{array}$ \\
\hline $\begin{array}{l}\text { Wang et } \\
\text { al. (2011) }\end{array}$ & LFP & 200 & $\begin{array}{l}0.5 \mathrm{C}, 2 \mathrm{C}, \\
6 \mathrm{C}, 10 \mathrm{C}\end{array}$ & $\begin{array}{l}\text { Experimental results indicated that the capacity loss was strongly } \\
\text { affected by time and temperature, but minimally by charging } \\
\text { rates. }\end{array}$ \\
\hline
\end{tabular}

Accelerated battery degradation can be caused by charging and discharging patterns, such as repeatedly using the entire capacity of a battery, or repeated rapid charging (IEA 2020).

Charging (and discharging) patterns are measured via 'C-rates' per hour, so that $1 \mathrm{C}$-rate means that the battery will be completely charged or discharged in 1 hour at that level of current. Ignoring the conversion efficiencies, the $\mathrm{C}$-rate can be calculated by dividing the charger's power level by the battery capacity or size. For a given charging power, the larger the battery capacity, the lower the C-rate for charging.

Battery life is also dependent upon the type or chemistry of the battery used in the EV, which can be Lithium Nickel Manganese Cobalt Oxide (NMC), Lithium Nickel Cobalt Aluminum Oxide (NCA), or Lithium Iron Phosphate (LFP).

\section{Findings}

A review of literature on the impact of charging speeds on battery life was conducted using keywords of 'Lithium battery degradation' and 'Lithium battery life' on Google Scholar. Although there is considerable work on the different degradation mechanisms, few studies quantify degradation through empirical experiments on batteries suitable for EVs. Even less research maintains uniformity across discharge rates to enable a direct comparison of the impact of charging rates. The remaining literature is summarized in Table 1 and shows that for NMC batteries, charging rates above $1 \mathrm{C}$ rate adversely affects the battery life whereas, for LFP batteries, the battery life is not significantly affected by charging rates up to $4 \mathrm{C}$.

Thus, rapid chargers can hasten the degradation of batteries in vehicles with NMC battery chemistry. However, the battery management systems in vehicles are set to limit the level of power received to prevent accelerated degradation. 
Table 2: Battery chemistry, capacity, charging power limits, and C-rates

\begin{tabular}{|c|c|c|c|c|c|c|c|c|}
\hline \multirow{2}{*}{$\begin{array}{c}\text { EV model } \\
\text { (market share } \\
\text { of } \mathrm{BEVs}^{1} \text { ) }\end{array}$} & \multirow[t]{2}{*}{$\begin{array}{l}\text { Battery } \\
\text { chemistry } 2\end{array}$} & \multirow{2}{*}{$\begin{array}{c}\text { Battery } \\
\text { capacity or } \\
\text { size }^{3}(\mathrm{kWh})\end{array}$} & \multicolumn{2}{|c|}{$\begin{array}{l}\text { Charging power } \\
\text { limit }^{3}\end{array}$} & \multicolumn{4}{|c|}{$\begin{array}{l}\text { C-rate in per hour by charger type (charger power } \\
\text { limit } \mathrm{kW} \text { ) }\end{array}$} \\
\hline & & & $\begin{array}{l}\mathrm{AC}^{4} \\
(\mathrm{~kW})\end{array}$ & $\begin{array}{c}\mathrm{DC} \\
(\mathrm{kW})\end{array}$ & $\begin{array}{c}\mathrm{AC}^{4} \\
\text { Home } \\
\text { charging } \\
(7 \mathrm{~kW})\end{array}$ & $\begin{array}{c}\mathrm{AC}^{4} \\
\text { Fast } \\
\text { charging } \\
(22 \mathrm{~kW})\end{array}$ & $\begin{array}{l}\mathrm{DC} \\
\text { rapid } \\
(50 \\
\mathrm{kW})\end{array}$ & $\begin{array}{c}\text { DC } \\
\text { ultra- } \\
\text { rapid } \\
(150 \mathrm{~kW})\end{array}$ \\
\hline $\begin{array}{l}\text { Nissan Leaf } \\
(22 \%)\end{array}$ & NMC & 40 or 62 & 6.6 & 49 & $0.11 \mathrm{C}$ & $0.11 C$ & $0.79 C$ & $N A^{5}$ \\
\hline $\begin{array}{l}\text { Tesla Model } 3 \\
(17 \%)\end{array}$ & NCA & 55 & 11 & 170 & $0.13 C$ & $0.20 \mathrm{C}$ & $0.91 C$ & $2.7 \mathrm{C}$ \\
\hline BMW i3 (6\%) & NMC & 42 & 11 & 49 & $0.17 \mathrm{C}$ & $0.26 \mathrm{C}$ & $1.17 \mathrm{C}$ & $N A^{5}$ \\
\hline $\begin{array}{l}\text { Volkswagon } \\
\text { e-Golf }(5 \%)\end{array}$ & NMC & 35.8 & 7.2 & 40 & $0.20 \mathrm{C}$ & $0.20 \mathrm{C}$ & $1.12 \mathrm{C}$ & $N A^{5}$ \\
\hline $\begin{array}{l}\text { Renault ZOE } \\
(9 \%)\end{array}$ & NMC & 55 & 22 & 46 & $0.13 C$ & $0.40 \mathrm{C}$ & $0.84 C$ & $N A^{5}$ \\
\hline $\begin{array}{l}\text { Tesla Model S } \\
(7 \%)\end{array}$ & NCA & 100 & 16.5 & 250 & $0.07 \mathrm{C}$ & $0.17 C$ & $0.5 \mathrm{C}$ & $1.5 \mathrm{C}$ \\
\hline $\begin{array}{l}\text { Kia e-Niro } \\
(3 \%)\end{array}$ & NMC & 42 or 67 & 7.2 & 50 & $0.10 \mathrm{C}$ & $0.11 C$ & $0.75 \mathrm{C}$ & $N A^{5}$ \\
\hline $\begin{array}{l}\text { Jaguar I-Pace } \\
(6 \%)\end{array}$ & NMC & 90 & 11 & 104 & $0.08 \mathrm{C}$ & $0.12 \mathrm{C}$ & $0.56 \mathrm{C}$ & $1.2 \mathrm{C}$ \\
\hline $\begin{array}{l}\text { Tesla Model } \\
\text { X (4\%) }\end{array}$ & NCA & 100 & 16.5 & 250 & $0.07 \mathrm{C}$ & $0.17 \mathrm{C}$ & $0.5 \mathrm{C}$ & $1.5 \mathrm{C}$ \\
\hline $\begin{array}{l}\text { Hyundai } \\
\text { IONIQ (2\%) }\end{array}$ & NMC & 40 & 7.2 & 44 & $0.18 \mathrm{C}$ & $0.18 \mathrm{C}$ & $1.10 \mathrm{C}$ & $N A^{5}$ \\
\hline
\end{tabular}

\footnotetext{
${ }^{1}$ Department for Transport 2020.

${ }^{2}$ https://pushevs.com/2020/04/04/comparison-of-different-ev-batteries-in-2020/ Accessed January 2021.

3 https://ev-database.uk/ Accessed January 2021.

${ }^{4}$ The electricity that comes into our households from the grid is Alternating Current (AC). Most modern electronics, including EVs, use Direct Current (DC) for their operation. During AC charging of EVs, current from the grid is converted into DC using the on-board inverter, whereas in DC charging, the rapid or ultra-rapid charger converts AC into DC.

${ }^{5}$ Many models do not currently support the use of ultra-rapid chargers.
}

Therefore, the impact of rapid charging also depends upon these limits, which can be used as the numerator instead of the charger's power level in calculating C-rate. Table 2 shows the battery chemistry, size and any power limits of the top ten battery-only EV models sold in the UK (Department for Transport 2020). The vehicle power limit or the maximum power capacity of the charger, whichever is lower, is then used to calculate the respective C-rate.

Table 2 shows that EV models with NMC batteries have DC charging power limits that prevent the $\mathrm{C}$-rate from going much above $1 \mathrm{C}$. Even without power limits set by battery management systems, none of these EVs come close to exceeding $1 \mathrm{C}$ whilst using fast chargers. For rapid and ultra-rapid charging, the exceedance is minimal due to the power limits. Consider the Jaguar I-Pace: the additional degradation is limited to around $3 \%$ in 300 cycles when using ultrarapid chargers. Such charging rates can reduce the NMC battery life by up to $10 \%$ as against home, fast or rapid charging in 300 cycles. Thus, regular rapid and ultra-rapid charging does reduce battery life, but this is minimal due to battery management systems. 


\section{Acknowledgements}

This research was funded by the 'Park and Charge' project, awarded to the University of Oxford by Innovate UK, under project reference: 105428.

Submitted: January 28, 2021 AEDT, Accepted: March 12, 2021 AEDT

This is an open-access article distributed under the terms of the Creative Commons Attribution 4.0 International License (CCBY-SA-4.0). View this license's legal deed at https://creativecommons.org/ licenses/by-sa/4.0 and legal code at https://creativecommons.org/licenses/by-sa/4.0/legalcode for more information. 


\section{REFERENCES}

Anseán, D., M. Dubarry, A. Devie, B.Y. Liaw, V.M. García, J.C. Viera, and M. González. 2016. "Fast Charging Technique for High Power LiFePO4 Batteries: A Mechanistic Analysis of Aging.” Journal of Power Sources 321 (July): 201-9. https://doi.org/10.1016/j.jpowsour.2016.04.140.

Biresselioglu, Mehmet Efe, Melike Demirbag Kaplan, and Barbara Katharina Yilmaz. 2018. "Electric Mobility in Europe: A Comprehensive Review of Motivators and Barriers in Decision Making Processes." Transportation Research Part A: Policy and Practice 109 (March): 1-13. https://doi.org/10.1016/j.tra.2018.01.017.

Department for Transport. 2020. "VEH0133: Licensed Ultra Low Emission Vehicles by Body Type and Propulsion or Fuel Type: United Kingdom.” Ultra Low Emissions Vehicles (ULEVs).

https:/assets.publishing.service.gov.uk/government/uploads/system/uploads/attachment_data/ file/942249/veh0133.ods.

Engel et al. 2019. "Second-Life EV Batteries: The Newest Value Pool in Energy Storage.” Our Insights. https://www.mckinsey.com/industries/automotive-and-assembly/our-insights/secondlife-ev-batteries-the-newest-value-pool-in-energy-storage\#.

Gao, Yang, Jiuchun Jiang, Caiping Zhang, Weige Zhang, Zeyu Ma, and Yan Jiang. 2017. "LithiumIon Battery Aging Mechanisms and Life Model under Different Charging Stresses." Journal of Power Sources 356 (July): 103-14. https://doi.org/10.1016/j.jpowsour.2017.04.084.

IEA. 2020. “Global EV Outlook 2020.” Paris: IEA. https://www.iea.org/reports/global-evoutlook-2020.

Somerville, L., J. Bareño, S. Trask, P. Jennings, A. McGordon, C. Lyness, and I. Bloom. 2016. "The Effect of Charging Rate on the Graphite Electrode of Commercial Lithium-Ion Cells: A PostMortem Study." Journal of Power Sources 335 (December): 189-96. https://doi.org/10.1016/ j.jpowsour.2016.10.002.

Wang, John, Ping Liu, Jocelyn Hicks-Garner, Elena Sherman, Souren Soukiazian, Mark Verbrugge, Harshad Tataria, James Musser, and Peter Finamore. 2011. "Cycle-Life Model for GraphiteLiFePO4 Cells." Journal of Power Sources 196 (8): 3942-48. https://doi.org/10.1016/ j.jpowsour.2010.11.134. 